\title{
The limit of the sea: the bathyal fauna of the Levantine Sea*
}

\author{
BELLA S. GALIL \\ National Institute of Oceanography, Israel Oceanographic and Limnological Research, P.O.B. 8030, \\ Haifa 31080, Israel. E-mail: bella@ocean.org.il
}

\begin{abstract}
SUMMARY: In the present study, the fish, molluscs, crustaceans and echinoderms collected at depths between 734 and 1558 m during a series of cruises conducted between 1988 and 1999 off the coast of Israel, supplemented by a photographic survey carried out southwest of Cyprus at a depth of $2900 \mathrm{~m}$, were analysed. The main objectives were to determine the faunal composition of the bathybenthic assemblages in the southeastern Levantine Sea, and to compare them with the western Mediterranean assemblages in order to elucidate whether general trends in their bathymetric distribution and population density may be related to environmental/geographic factors. Considering the sampling effort, the diverse gear used and the extended period of sampling, we may assume that the low number of species and specimens recorded actually reflects a lowdiversity, low-density deep water fauna. The faunal scarcity may cause a different parcelling of the populations which is reflected in bathymetric distributions that in many cases extend to greater depths than in the Western Mediterranean. The Levantine bathybenthos is composed of autochthonous, self-sustaining populations of opportunistic, eurybathic species that have settled there following the last sapropelic event.
\end{abstract}

Key words: Mediterranean Sea, Levantine Sea, bathyal, diversity, abundance, bathymetric distribution, new records, fish, Decapoda, Amphipoda, Cumacea, Mollusca.

RESUMEN: El LÍMITE DEL MAR: LA FAUNA BATIAL DEL MAR LEVANTINO. - En este estudio se analizan los peces, los moluscos, los crustáceos y los equinodermos recolectados a profundidades entre 734 y $1558 \mathrm{~m}$, durante una serie de campañas de muestreo realizadas entre 1988 y 1999 delante de las costas de Israel. Estas muestras se complementan con fotografías submarinas realizadas a $2900 \mathrm{~m}$ de profundidad al suroeste de Chipre. El objetivo es determinar la composición faunística de las asociaciones batipelágicas en el sureste del mar Levantino y compararla con las asociaciones del Mediterráneo occidental, con el fin de observar si existen tendencias generales en su distribución batimétrica y en las densidades de las poblaciones, de manera que puedan ser relacionadas con factores geográficos y ambientales. Considerando el esfuerzo realizado en muestreo, los diversos artes usados y el amplio período de muestreo, podemos asumir que el bajo número de especies y especímenes registrado refleja realmente la baja diversidad y la baja densidad de la fauna de las aguas profundas. La escasa fauna puede causar un distinto parcelado de las poblaciones que se refleja en su distribución batimétrica la qual en muchos casos se extiende hacia las más grandes profundidades del Mediterráneo occidental. El batibentos levantino esta compuesto por especies autóctonas, poblaciones de especies oportunistas auto-sostenibles y euribáticas, que colonizaron estos fondos desde el último evento sapropélico.

Palabras clave: mar Mediterráneo, mar Levantino, batial, diversidad, abundancia, distribución batimétrica, nuevas citas, peces, Decapoda, Amphipoda, Cumacea, Mollusca.

\section{INTRODUCTION}

Undeterred by Forbes' (1844: 170) notorious observation "Zero of Animal Life probably about 300

*Received June 9, 2003. Accepted January 27, 2004. fathoms", the scientific exploration of the Levantine bathyal biota commenced with the extensive voyages of the Pola (1890-1893). In 1910 the Danish Oceanographic Expedition to the Mediterranean, aboard the Thor, sampled nine sites along the western limits of the Levantine Sea, from Cyrenaica to 
Rhodes. However, as that expedition was concerned mainly with plankton investigations, and "dredgings were only occasionally made ... the result will thus necessarily be but poor" (Stephensen, 1915). The Lamont Geological Observatory research vessel Vema collected few deep benthic samples in 1958 (Barnard, 1964). Four deep-water shark species were collected in five hauls using bottom long-line at depths of 1330$1440 \mathrm{~m}$ off the Mediterranean coast of Israel in 1985 (Golani, 1987). The German research vessel Meteor [cruise 5] in 1987, collected benthic samples at sites between Crete and Israel at depths ranging between 95 and 4396 m during a ten-day sojourn (Janssen, 1989). The handful of deep sea fishes gathered persuaded Klausewitz (1989) that "this collecting trip confirmed the paucity of the deep sea fish fauna in the eastern basin of the Mediterranean". The Meteor returned in 1993 [cruise 25], to collect deep-sea biota from the region between Crete, Cyprus and Egypt at depths ranging between 194 and $2812 \mathrm{~m}$, as well as sea bed litter (Galil et al., 1995). The fauna of Eratosthenes Seamount, south of Cyprus, was briefly sampled by the Poseidon [cruise 201/2] in February 1994 (Galil and Zibrowius, 1998). Among the faunistic explorations of the Levantine bathyal, only Gilat and Gelman (1984), and Jones in Priede and Bagley (2000) made use of photographic equipment to observe the deep fauna in its environment.

The meagre number and extent of the explorations prompted Fredj and Laubier (1985), in their review on the deep Mediterranean benthos, to declare that "...the southern part of the Levant Sea has practically never been studied".

The present study analysed the data obtained from samples collected by a box corer and a bottom trawl fitted with a plankton net during a series of cruises conducted between 1988 and 1999 as part of pollution monitoring surveys by the Israel Oceanographic and Limnological Research (IOLR) off the coast of Israel, at depths between 734 and $1558 \mathrm{~m}$, supplemented by a photographic survey carried out southwest of Cyprus, at a depth of 2900 $\mathrm{m}$. The main objectives were to determine the faunal composition of the bathybenthic assemblages in the southeastern Levantine Sea, and to compare them with the western Mediterranean assemblages in order to elucidate whether general trends in their bathymetric distribution and population density may be related to environmental factors. Although restricted to a small area and to the depth range mentioned above, this study has significantly increased our knowledge of the Levantine deep sea fauna.

\section{STUDY AREA AND METHODS}

The Levant Sea occupies the easternmost Mediterranean, east of the line connecting Rhodes and the coast of Cyrenaica. It is isolated from the deep Atlantic waters by the topographical and hydrological barriers posed by the shallow Gibraltar Straits and the Siculo-Tunisian sill. The Levantine deep water mass is distinguished by salinity and temperature values that are higher than in the rest of the Mediterranean $\left(\mathrm{T}<13.8^{\circ} \mathrm{C}, \mathrm{S}<38.74\right.$, below $700 \mathrm{~m}$ ) (Hecht et al., 1988). The Levantine Sea is ultra-oligotrophic (Berman et al., 1984; Krom et al., 1991): Chlorophyll $a$ concentrations are as low as $0.4 \mu \mathrm{g}^{-1}$ nearshore, and decrease offshore to 0.05 $\mu \mathrm{g} \mathrm{l}^{-1}$ (Berman et al., 1986; Yacobi et al., 1995).

The area investigated is located off the coast of Israel, at depths between 734 and $1558 \mathrm{~m}$. The material was collected during monitoring surveys of two deepwater waste-dumping sites: an acidic sludge disposal site off Haifa (between $33^{\circ} 00^{\prime} \mathrm{N} 34^{\circ} 37^{\prime} \mathrm{E}$ and $33^{\circ} 01^{\prime} \mathrm{N} 34^{\circ} 47^{\prime} \mathrm{E}$ ), a coal fly ash disposal site off Hadera (between $32^{\circ} 38^{\prime} \mathrm{N} 34^{\circ} 02^{\prime} \mathrm{E}$ and $32^{\circ} 36^{\prime} \mathrm{N}$ $34^{\circ} 16^{\prime} \mathrm{E}$ ), and a control site off Atlit (between $32^{\circ} 53^{\prime} \mathrm{N} 34^{\circ} 10^{\prime} \mathrm{E}$ and $\left.32^{\circ} 51^{\prime} \mathrm{N} 34^{\circ} 23^{\prime} \mathrm{E}\right)$. The samples were collected aboard the R/V Shikmona (720 HP; $27 \mathrm{~m}$ ), using a modified Agassiz benthic trawl (2.3 m width and $0.9 \mathrm{~m}$ height), a $45 \mathrm{ft}$ Marinovichtype deep water trawl (codend mesh $6 \mathrm{~mm}$ ) with a 0.5 $\mathrm{mm}$ plankton net secured atop, and a $0.062 \mathrm{~m}^{2}$ boxcorer with an effective penetration of $40 \mathrm{~cm}$ (Ocean Instruments model $700 \mathrm{AL}$ ) (Table 1). The samples were preserved in $10 \%$ buffered formalin aboard ship. In the laboratory, the samples were washed and sieved through a $500 \mu \mathrm{m}$ mesh, preserved in $70 \%$ alcohol, stained in Rose Bengal and sorted.

The photographic survey took place southwest of Cyprus, at depth of $2900 \mathrm{~m}$. A total of 80 hours of video were recorded utilising a remote operating vehicle (Remora 6000, Phoenix).

\section{RESULTS}

\section{Fishes}

A total of 566 specimens identified to 31 species were collected during the study. Four species were new records for the eastern Mediterranean, four species were new records for the Levantine Sea and five species were newly recorded from the Israeli coast (Galil and Goren, 1994; Goren and Galil, 
TABLE. 1. - List of cruises: date, location, depth, type of equipment and number of samples (n)

\begin{tabular}{|c|c|c|c|c|c|}
\hline Date & Location & Depth (m) & Agassiz (n) & Marinovich (n) & Plankton (n) \\
\hline XI 1988 & Hadera & $1370-1500$ & 4 & & \\
\hline I 1989 & Haifa & $1345-1450$ & 3 & & \\
\hline V,VI 1989 & Atlit & $1422-1527$ & 5 & & \\
\hline X1989 & Haifa & $1240-1441$ & 5 & & \\
\hline V 1990 & Hadera & $1400-1500$ & 5 & & \\
\hline VI 1990 & Atlit & $1400-1550$ & 2 & & \\
\hline V 1991 & Hadera & $1308-1500$ & 9 & 5 & \\
\hline III 1993 & Hadera & $1387-1494$ & 4 & & \\
\hline IV 1993 & Atlit & 1435 & & 1 & \\
\hline X 1993 & Haifa & $1360-1436$ & & 4 & 4 \\
\hline XII 1993 & Hadera & $1300-1500$ & 4 & 1 & \\
\hline XII 1994 & Hadera & $1290-1482$ & & 8 & 8 \\
\hline I 1995 & Atlit & $1000-1561$ & & 8 & 7 \\
\hline X 1995 & Hadera & $1279-1485$ & & 12 & 8 \\
\hline XI 1995 & Haifa & $1224-1471$ & & 11 & 9 \\
\hline IX 1996 & Atlit & $1427-1562$ & & 8 & 6 \\
\hline X,XI 1996 & Hadera & $1281-1529$ & & 16 & 16 \\
\hline IX 1997 & Hadera & $1227-1454$ & & 9 & 7 \\
\hline IX 1997 & Haifa & $1227-1439$ & & 8 & 8 \\
\hline XI 1998 & Hadera & $1243-1500$ & & 14 & 13 \\
\hline X 1999 & Atlit & $1413-1557$ & & 7 & 7 \\
\hline X 1999 & Hadera & $1260-1485$ & & 14 & 13 \\
\hline
\end{tabular}

1997; Goren and Galil, 2002). Bathypterois mediterraneaus and Nezumia sclerorhynchus were the most common species, with nearly 38 and $27 \%$ of the specimens respectively. The Myctophidae and Macrouridae were represented by most species, with five and four species respectively (Appendix 1).

Three species were identified from the video records photographed southwest of Cyprus, at 2900 $\mathrm{m}$, Bathypterois mediterraneus, Cataetyx laticeps, and Chauliodus sloani - none of which had been photographed previously in the Levantine bathyal.

\section{Decapod crustaceans}

A total of 2819 specimens identified to 19 species were collected during the study. The Mediterranean endemic geryonid crab Chaceon mediterraneus was photographed southwest of Cyprus, at $2900 \mathrm{~m}$. In total, one species, Levantocaris hornungae, was described as new to science, five species were new records for the Levantine Sea and eight species were newly recorded from the Israeli coast (Galil and Clark, 1993; Galil and Goren, 1994; Appendix). Polycheles typhlops, Acanthephyra eximia, Aristeus antennatus, and Geryon longipes were the most prevalent and common species, with nearly $48,25,14$ and $7 \%$ of the specimens respectively.

\section{Amphipod crustaceans}

A total of 673 amphipod specimens identified to 22 species were collected during the study
(Sorbe and Galil, 2002). Seventeen species constitute new records for the Levantine Sea, and four were newly recorded from the Israeli coast (Appendix 1). Four of the 22 deep-sea amphipod species collected are Mediterranean endemics. Two of the endemic species were the most frequently collected and the dominant species in the samples: Ileraustroe ilergetes and Pseudotiron bouvieri were identified in 38 and 23 of our 44 samples, with 40 and $15 \%$ of the specimens respectively. Rhachotropis rostrata and Stegophaloides christianiensis were the next most common species, each with nearly $11 \%$ of the specimens, and 23 and 22 of our samples respectively.

\section{Cumaceans}

A total of 575 specimens identified to 12 species were collected from three trawling campaigns in 1988-99. As the deep-water cumaceans of the Levantine Sea had not been studied previously, they all constitute new records (Corbera and Galil, 2001). Procampylaspis bonnieri was the most frequently collected and the dominant species in the samples, with 193 specimens. Campylaspis glabra was the next most common species, with nearly 13\%, followed by Makrokylindrus longipes, Platysympus typicus and Procampylaspis armata, each with nearly $11 \%$ of the specimens. These species were identified in 22, 19, 18 and 17 of our 27 samples respectively. 


\section{Molluscs}

A total of 4580 molluscan specimens identified to 42 species were collected (Bogi and Galil, 2004). Four species constitute new records for the eastern Mediterranean, and 6 are newly recorded from the Levantine Sea. The most common benthic molluscs in depths greater than $1000 \mathrm{~m}$ off the Israeli coast are Yoldia micrometrica, Kelliella abyssicola, Cardyomia costellata, Entalina tetragona, Benthomangelia macra, Benthonella tenella and Bathyarca pectunculoides present in $83,77,76,63$, 59,50 and 33 out of the 90 samples, with 827,561 , $437,485,112,230$ and 64 live specimens respectively. Much of the material examined consisted of juvenile specimens and empty shells - only 23 species were represented by living specimens, 11 of which were represented solely by juvenile specimens.

\section{Echinoderms}

Sixteen specimens of a single synallactid holothurian species, Mesothuria intestinalis, were collected.

\section{DISCUSSION}

Examination of the results of a total of 167 trawl hauls from a series of 22 cruises conducted between 1988 and 1999 off the coast of Israel, supplemented by a photographic survey carried out southwest of Cyprus, allows us to compare the faunal composition of the Levantine Sea bathyal with that reported from the opposite end of the Mediterranean, the Catalan Sea in the northwestern Mediterranean, where extensive surveys of the deep water fauna have resulted in a comprehensive corpus of data (Abelló and Valladares, 1988; Stefanescu et al., 1992, 1993; Cartes, 1993; Cartes and Sorbe, 1993, 1997, 1999; Cartes and Sardà, 1993).

\section{Fishes}

An extensive survey of the demersal fishes of the Catalan Sea consisting of 100 samples taken at depths between 960 and 2251 m collected 31 species (Stefanescu et al., 1992). Thirteen of the 20 demersal and benthopelagic fish species collected during the IOLR monitoring surveys are common to both lists. Bathypterois mediterraneus is by far the pre- dominant species in both surveys, but of the next most common species in the Catalan Sea, the morid Lepidion lepidion and the macrourid Coryphanoides guentheri, the former is absent from our samples and the latter is known from 3 specimens. Bathypterois mediterraneus was the dominant species also on the lower slope (1400-1600 m) in the Algerian basin (Moranta et al., 1998), but of the next most common species there, Alepocephalus rostratus and Coelorhynchus labiatus [= Caelorinchus mediterraneus] the former is absent from our samples and the latter is known from 16 specimens. Conversely, of the next most common species in our survey, Nezumia sclerorhynchus and Nettastoma melanurum, the former is absent from the Catalan Sea samples and the latter is known from 13 specimens. In a survey of the demersal fish in the Eastern Ionian Sea at depths between 600 and 2600 m, B. mediterraneus, Mora moro, N. sclerorhynchus and $N$. melanurum were the most common species at depths greater than $800 \mathrm{~m}$ (D'Onghia et al., 2004), whereas in Heraklion Bay, Crete, at $1000 \mathrm{~m}$ Mora moro was by far the most common species (Kallianiotis et al., 2000).

Though a photographic survey by a remotely operated vehicle is limited to the large, non-burrowing, non-evasive organisms, in conjunction with qualitative data obtained by trawling, it provides a more complete view of deep-sea megafaunal communities. Among the faunistic explorations of the Levantine bathyal, only Gilat and Gelman (1984), and Jones in Priede and Bagley (2000) made use of photographic equipment to observe the deep fauna in its environment. Gilat and Gelman employed a free-fall camera positioned on top of a bait holder, taking still photographs at 5 minute intervals for 18 hours, at six sites between Israel and Cyprus. The deepest site, at $1490 \mathrm{~m}$, was located off Cyprus. Jones used an autonomous unmanned lander platform equipped with cameras and sonars to track movements of fish attracted to bait in the Cretan sea (1500-2500 m), Rhodes Basin (2300 - $3850 \mathrm{~m})$, and Ierapetra Basin (3080-4172 m). Both surveys utilised bait, thus attracting facultative or obligate scavengers. Off Cyprus, at $1490 \mathrm{~m}$ depth, the sharks Centrophorus granulosus and Etmopterus spinax were the most abundant species, constituting over $83 \%$ of the records (Gilat and Gelman, 1984). In the Cretan Sea (1500-3850 m) and Rhodes Basin (2300 - 3850 m), again sharks (Hexanchus griseus, Galeus melastomus, Centrophorus spp., Centroscymnus coelolepis, and Etmopterus spinax) predominated, 
together with the teleost fishes Chalinura mediterranea and Lepidion lepidion (Jones in Priede and Bagley, 2000). Our survey, transacted without resorting to bait, documented the site-typical faunal complement. There is no doubt that the abundance of the Levantine deep water megafauna is remarkably low: in 80 hours of video documentation only three fishes, B. mediterraneus, Cataetyx laticeps and Chauliodes sloani, were recorded. Although our methods were not sufficient for quantitative comparison with studies made in the western Mediterranean, the small number of species and specimens confirms the ichthyofaunal scarcity of the Levantine Sea, not only compared with the adjacent Atlantic Ocean (Haedrich and Merrett, 1988), but also with the western Mediterranean.

\section{Decapod crustaceans}

Twenty-one bathyal decapods were reported from a faunistic survey of the Catalan sea conducted between 1983 and 1985 consisting of 39 trawl samples taken between 1020 and 2011 m (Abelló and Valladares, 1988), and 28 species were identified from 57 samples trawled between 862 and 2265 $m$ in 1988 and 1989 (Cartes, 1993). In all, 29 benthic, mesopelagic and bathypelagic decapod crustaceans have been identified from the Catalan deep sea. Fifteen of the 20 decapod species collected during the IOLR monitoring surveys are common to both localities. Of the most common species at 1350-1549 $\mathrm{m}$ in the Catalan sea (Cartes, 1993) Aristeus antennatus, Acanthephyra eximia, Pontophilus norvegicus, Polycheles sculptus and Munida tenuimana - only the first two species occur in our samples. The most common species in the Levantine samples, Polycheles typhlops, was more common on the middle slope than on the lower slope in the Catalan sea. The cold stenothermal Sergestes arcticus and Pontophilus norvegicus are absent, though the pelagic larvae of the former have been found at a depth of $10 \mathrm{~m}$, and the latter was recorded at $50 \mathrm{~m}$ (d'Udekem d'Acoz, 1999). Polycheles sculptus, Munida tenuimana and Munidopsis serricornis $[=M$. tridentata $]$ are known only from the western basin of the Mediterranean. Plesionika narval, Munidopsis marionis and Bathynectes maravigna were identified from the Levantine samples and from the western Mediterranean, but not from the surveys in the Catalan sea. In a survey of the decapod fauna of the Eastern Ionian Sea at depths between 1000 and $1500 \mathrm{~m}$, A. antennatus was as abundant as P. typhlops (Company et al., 2004), whereas in the Levantine Sea P. typhlops is more than three times as abundant as A. antennatus.

\section{Amphipod crustaceans}

Fifty-two bathyal amphipod crustaceans were reported from a survey of the Catalan Sea suprabentic bathyal communities (552 - $1808 \mathrm{~m}$ ) conducted in 1989 and consisting of 10 hauls (Cartes and Sorbe, 1993), and 82 species were identified from 20 samples trawled between 389 and $1859 \mathrm{~m}$ in 1991-92 (Cartes and Sorbe, 1999), compared with the 22 species identified from 27 hauls in the Levant Sea. All but one of the amphipod species collected during the IOLR monitoring surveys, Stegophaloides christianiensis, have been recorded from the Catalan Sea. The dominant species on the upper part of the lower slope (1250-1355 m) in the Catalan Sea was Rhachotropis caeca, whereas on the lower part $(1860 \mathrm{~m})$ Ileraustroe ilergetes and Rhachotropis caeca predominate (Cartes and Sorbe, 1999). Ileraustroe ilergetes is the most common and prevalent species in the Levant Sea, present in $86 \%$ of the samples, as compared with 6.3 and $20.8 \%$ respectively in the upper and lower parts of the lower slope of the Catalan Sea. However, whereas $R$. caeca appears in $36.3 \%$ of the samples taken between 1250 and $1355 \mathrm{~m}$ on the Catalan slope, and its congener, $R$. rostrata, in only $4.3 \%$ of these samples, along the Levantine coast their abundance is reversed: $R$. caeca is present in $33 \%$ of the samples whereas $R$. rostrata is present in over half. The next most common species on the lower slope in the Catalan Sea, Bathymedon sp. A and Andaniexix mimonectes, are entirely absent from our samples. Only four species collected in our study are Mediterranean endemics, whereas of the 154 deep sea amphipods known from the Mediterranean as a whole, 71 are endemic species (Bellan-Santini, 1990).

\section{Cumaceans}

Twenty-eight bathyal cumacean species were reported from a survey of the muddy bottoms of the slope (552-1808 m) of the Catalan sea (Cartes and Sorbe, 1993), and 32 species were identified from 21 samples trawled between 389 and $1859 \mathrm{~m}$ in 1991 and 1992 (Cartes, 1997), compared with the 12 species identified from 27 hauls in the Levant Sea. All of the cumacean species collected during the 
IOLR monitoring surveys have been recorded from the Catalan Sea. The dominant species on the lower slope in the Catalan Sea was Cyclaspis longicaudata (Cartes and Sorbe, 1993, 1997), whereas only 11 specimens were identified in our samples. The most common and abundant species in the Levantine samples, Procampylaspis bonnieri, was more common on the middle slope (862-989 m) than on the lower slope in the Catalan sea (Cartes and Sorbe, 1993). The characteristic bathyal cumacean assemblage in the western Mediterranean, consisting of $C$. longicaudata, $P$. bonnieri, $P$. armata, Bathycuma brevirostre and Platysympus typicus, is somewhat modified in the Levant Sea, where C. longicaudata is replaced by Makrokylindrus longipes, the latter species again being more common on the middle slope than on the lower slope in the Catalan sea (Cartes and Sorbe, 1993, 1997).

\section{Molluscs}

Salas (1996:90) found that the molluscan fauna in the Alboran Sea "becomes scarce below $1000 \mathrm{~m}$ with hardly more than one living specimen per haul, and the deepest samples at $1433 \ldots$ and $1742 \mathrm{~m} \mathrm{...}$ were barren". Di Geronimo et al. (2001), who examined the composition and depth range of molluscs from the bathyal thanatocoenoses of the southern Tyrrhenian Sea, have established that the most common benthic species at $1139-1536 \mathrm{~m}$ were, in descending order, Benthonella tenella, Kelliella abyssicola, Ennucula corbuloides, and Microgloma tumidula, of which only the first two species occur in our samples. The most common benthic molluscs at depths greater than $1000 \mathrm{~m}$ off the Israeli coast are the Atlanto-Mediterranean and Boreal Benthonella tenella, Kelliella abyssicola, Yoldia micrometrica, Cardyomia costellata, Entalina tetragona, Benthomangelia macra, and Bathyarca pectunculoides. The same species were identified by Janssen (1989) in material sampled by boxcore at a station off the Israeli coast at $1217 \mathrm{~m}$. Though all are present in the southern Tyrrhenian Sea, except for the first three species, they are rather rare (Di Geronimo et al., 2001).

\section{Levantine low-diversity, low-density deep water fauna}

"The floro-faunistic impoverishment of the eastern Mediterranean compared with the western Mediterranean richness in species" (Sarà, 1985) has been generally accepted, as well as the perception of a gradational decrease from west to east that is more conspicuous for the deep benthos than for the whole fauna (Fredj and Laubier, 1985): a survey of the biota of the Balearic basin and the western and eastern Ionian Sea at depths between 1000 and $1500 \mathrm{~m}$ has shown that the biomass of demersal decapods was 48268, 17440 and $4376 \mathrm{~g} \mathrm{~km}^{2}$ respectively (Company et al., 2004).

The low-diversity, low-density Levantine deep water fauna has long been presumed to be the poorest in the Mediterranean (Fredj, 1974). It was recognised that the scanty data may be due to sparse research efforts, that the "the different parts of the deep Mediterranean have not been equally sampled" (Fredj and Laubier, 1985), and that a particularly "limited amount of sampling [was] carried out in the eastern basins" (Bellan-Santini, 1990). It was even suggested that " $[t]$ he relative species richness of ... faunas of the different sectors of Mediterranean is better correlated with the level of research effort than the true species richness" (Bellan-Santini, 1990). As late as 1989 it was still possible for Klausewitz to wonder "whether an ecological or a geographical factor may be the reason for this limited distribution or whether the low number of zoological resp. [sic] oceanographical stations and research ships in the eastern half of the Mediterranean provides the reason for the lack of records." However, considering the sampling effort, the diverse gear used and the extended period of sampling, we may assume that the low number of species and specimens recorded does not stem solely from selective or inefficient gear, and is unlikely to increase much with additional surveys using similar sampling gear, though the number may be augmented by using other sampling methods.

\section{Bathymetric distribution of the Levantine deep water fauna}

As early as 1893 Marenzeller reported that species occur deeper in the Levant than elsewhere in the Mediterranean. Marenzeller's records were considered suspect, an artefact resulting from a "systematic mistake on the depth measurements" that "needs to be cleared up in the future" (Fredj and Laubier, 1985: 128). Recent studies published greater depth records in the Levantine Sea than in the western Mediterranean for 14 serpulid species, with a third of the depth extensions $>400 \mathrm{~m}$ (Ben Eliahu and Fiege, 1996). Twenty-two fish species 
were collected or photographed in the Levant Sea at depths greater than in the western Mediterranean (Goren and Galil, 1997, 2002). Several molluscs, Crenilabium exile, Yoldiella philippiana, Bathyarca philippiana, Thyasira granulosa, Allogramma formosa, and Cuspidaria rostrata, have been collected from greater depths in the Levantine Sea than in the southern Tyrrhenian Sea (Di Geronimo et al., 2001). Extension of the depth records was also reported for five of the bathyal amphipods collected off the Israeli coast, in the case of Bathymedon monoculodiformis, for as much as $1100 \mathrm{~m}$ (Sorbe and Galil, 2002). The Levantine Sea bathyfaunal scarcity may cause different parcelling of the populations that is reflected in bathymetric distributions that differ from those of the western Mediterranean deep water assemblages.

\section{Geographical and environmental factors and the Levantine deep water fauna}

The Mediterranean Pleistocene bathyal assemblages are more closely related to the Atlantic bathyal than to the present-day Mediterranean deep water fauna (Barrier et al., 1996). This disparity was attributed in part to the shallow Gibraltar sill that bars the deep water of the Atlantic Ocean from entering the Mediterranean, and the Mediterranean outflow that bars the entry of the deep water Atlantic fauna into the Mediterranean (Salas, 1996). The onset of the warm homothermy led to the demise of many cold stenothermic and stenohalinic species and the eventual impoverishment of the bathybenthos. In addition, the extreme oligotrophy of the Levantine Sea prevented settlement by members of the Atlantic bathyal that have been able to cross the shallow Gibraltar Straits and the Siculo-Tunisian sill $(<400$ m) (Pérès, 1985). The recurring stagnant (dysoxic and anoxic) Quaternary episodes resulted in a reduction, or even extinction of deep bottom-living fauna unable to avoid annihilation by adapting to shallower depth: Van Harten (1987) reported that "Several species of deep-water ostracodes that are still common in the Western Mediterranean became extinct in the Eastern Mediterranean basin at the onset of early Holocene S1 sapropel deposition". Bacescu (1985) believed that the bathyal bottoms of the Levant are still "unfavourable", or even "azoic", after the last sapropelic event, dated between 9000 and 6000 years BP, and George and Menzies (1968) suggested "that sufficient time has not elapsed to allow colonisation of the deep-sea floor".
The bathybenthic amphipods and cumaceans are indicative because the low mobility of their adults and their lack of a pelagic larval stage would restrict their dispersal into the Levantine Sea, effectively separated from the Atlantic Ocean by the Gibraltar and Siculo-Tunisian straits. Indeed, the common amphipods and cumaceans at depths greater than $1000 \mathrm{~m}$ off the Israeli coast are all eurybathic Atlanto-Mediterranean and Boreal species with an upper bathymetric range enabling them to overcome that barrier. None of the species with an upper bathymetric limit set at $400 \mathrm{~m}$ (Bellan-Santini, 1990) were collected during the study. This is the case for the molluscan fauna as well: K. abyssicola, C. costellata, E. tetragona and B. pectunculoides are eurybathic species with upper bathymetric range well within the circalittoral (>150 m), whereas both the more stenobathic $B$. macra and $B$. tenella have epipelagic larvae (Bouchet and Warén, 1979), enabling them to overcome the barrier posed by the shallow sills. However, 9 of the 12 thecostomate species collected in the Levantine Sea were recorded from cores dating to the upper and middle Pleistocene taken in the Ionian Sea (Grecchi, 1984) and, in fact, 12 of the 13 thecostomate species known from the western Mediterranean (Corselli and Grecchi, 1990) were collected in the present study off the coast of Israel. The evidence that the strictly epipelagic fauna is not impoverished in terms of species richness underscores the importance of the sills and/or the Quaternary extinctions in determining the character of the deep bottom-living fauna.

Bouchet and Taviani (1992) suggested that much of the Mediterranean deep-sea fauna is made-up of non-reproducing pseudopopulations that have entered the Mediterranean as meroplankton with the Atlantic inflow at Gibraltar. However, the populations of the most common benthic molluscs at depths greater than $1000 \mathrm{~m}$ off the Israeli coast are composed of both adult and juvenile specimens, and one species, Yoldia micrometrica, the most common and abundant species in the Eastern Mediterranean, is unrecorded from the westernmost part of the sea (Salas, 1996). Moreover, gravid benthic decapod crustaceans and fish were collected from the depths of the Levantine Sea (Galil and Goren, 1994; Goren and Galil, 1997; Fishelson and Galil, 2001).

Though much reduced in diversity and richness compared with the deep sea fauna of the western and central basins of the Mediterranean, the Levantine bathybenthos is composed of autochthonous, self- 
sustaining populations of opportunistic, eurybathic species that have settled there following the last sapropelic event.

\section{ACKNOWLEDGEMENTS}

The author is grateful to Prof. F. Sardà for the invitation to contribute to the special issue. Special thanks to C. Bogi, J. Corbera, J.P. Sorbe, and M. Goren, for their longstanding cooperation in the study of the Levantine bathybenthos.

\section{REFERENCES}

Abelló, P. and F.J. Valladares. - 1988. Bathyal decapod crustaceans of the Catalan Sea (Northwestern Mediterranean). Mésogée, 48: 97-102.

Barnard, J.L. - 1964. Deep-sea Amphipoda (Crustacea) collected by the R/V "Vema" in the eastern Pacific Ocean and the Caribbean and Mediterranean Seas. Bull. Am. Mus. Nat. Hist., 127: 1-146, figs. 1-33.

Bacescu, M. - 1985. The effects of the geological and physiological factors on the distribution of marine plants and animals in the Mediterranean. In: M. Moraitou-Apostolopoulou and V. Kiortsis, (eds.), Mediterranean marine ecosystems, NATO Conference Series 1. Ecology, 8: 195-212. New York, Plenum Press.

Barrier, P., I. Di Geronimo, Ch. Montenat, M. Roux, and H. Zibrowius. - 1989. Présence de faunes bathyales atlantiques dans le Pliocène et le Pleistocène de Méditerranée (détroit de Messine, Italie). Bull. Soc. Géolog. France, 4: 787-796.

Bellan-Santini, D. - 1990. Mediterranean deep-sea amphipods: composition, structure and affinities of the fauna. Prog. Oceanogr., 24: 275-287.

Ben Eliahu, M.N. and D. Fiege. - 1996. Serpulid tube-worms (Annelida: Polychaeta) of the Central and Eastern Mediterranean with particular attention to the Levant Basin. Senckenberg. Marit. 28(1/3): 1-51.

Berman, T., Y. Azov, Y., Schneller, P. Walline and D.W. Townsend. - 1986. Extent, transparency, and phytoplankton distribution of the neritic waters overlying the Israeli coastal shelf. Oceanol. Acta, 9: 439-447

Berman, T., D.W. Townsend, S.Z. El-Sayed, G.C. Trees and Y. Azov. - 1984. Optical transparency, Chlorophyll and primary productivity in the Eastern Mediterranean near the Israeli coast. Oceanol. Acta, 7: 367-372.

Bogi, C. and B.S. Galil. - 2004. The bathyenthic and pelagic molluscan fauna off the Levantine coast, Eastern Mediterranean. Boll. Malac., 39(5-8): 79-90.

Bouchet, P. and M. Taviani. - 1992. The Mediterranean deep-sea fauna: pseudopopulations of Atlantic species? Deep Sea Res., 39(2): 169-184.

Bouchet, P. and A. Warén. - 1979. Planktotrophic larval development in deep-water gastropods. Sarsia, 64: 37-40.

Cartes, J.E. - 1993. Deep-sea decapod fauna of the Western Mediterranean: bathymetric distribution and biogeographic aspects. Crustaceana, 65(1): 29-39.

Cartes, J.E. and F. Sardà. - 1993. Zonation of the deep-sea decapod fauna of the Catalan Sea (western Mediterranean). Mar. Ecol. Prog. Ser., 94: 27-34.

Cartes, J.E. and J.C. Sorbe. - 1993. Les communautés suprabenthiques bathiales de la mer Catalan (Méditerranée Occidentale): données preliminaries sur la répartition bathymétrique et l'abondance des crustacés péracarides. Crustaceana, 64(2): 155-171.

Cartes, J.E. and J.C. Sorbe. - 1997. Bathyal cumaceans of the Catalan Sea (North-western Mediterranean): faunistic composition, diversity and near-bottom distribution along the slope (between 389 and 1859 m). J. Nat. Hist., 31: 1041-1054.

Cartes, J.E. and J.C. Sorbe. - 1999. Deep-water amphipods from the Catalan Sea slope (western Mediterranean): bathymetric distribution, assemblage composition and biological characteristics. J. Nat. Hist., 33(8): 1133-1158.

Company, J.B., P. Maiorano, A. Tselepides, C.-Y. Politou, W. Plaity, G. Rotllant and F. Sardà. - 2004. Deep-sea decapod crustacean in the western and central Mediterranean Sea: preliminary aspects on species distribution, biomass and population structure. Sci. Mar., 68(Suppl. 3): 73-86.

Corbera, J. and Galil, B.S. - 2001. Cumaceans (Crustacea, Percarida) from the lower slope of the northern Israel coast, with a discussion on the status of Platysympus typicus. Israel $J$. Zool., 47: 135-146.

Corselli, C. and G. Grecchi. - 1990. Considerazioni sui Thecostomata attuali del Bacino Mediterraneo. Lavori S.I.M. Atti del Congresso di Parma, 24: 91-105.

Di Geronimo, I. - 1974. Molluschi bentonici in sedimenti recenti batiali e abissali dello Jonio. Conchiglie, 10(7-8): 133-172.

Di Geronimo, I., A. Rosso, R. La Perna and R. Sanfilippo. - 2001. Deep-sea $(250-1550 \mathrm{~m})$ benthic thanatocoenoses from the southern Tyrrhenian Sea. In: E.M. Faranda, L. Guglielmo and G. Spezie (eds.), Mediterranean Ecosystems Structures and Processes, pp. 277-287. Springer Verlag, Italia..

D'Onghia, G., D. Lloris, C. Y. Politou, L. Sion and J. Dokos. 2004. New records of deep-water teleost fish in three areas of the Mediterranean Sea with the updated bathymetric distribution of the species collected. Sci. Mar., 68(Suppl. 3): 171-183.

Fishelson, L. and B. S. Galil. - 2001. Gonad structure and reproductive cycle in the deep-sea hermaphrodite tripodfish, Bathypterois mediterraneaus (Chlorophthalmidae, Teleostei). Copeia (2): 556-560.

Forbes, E. - 1844. Report on the Mollusca and Radiata of the Aegean Sea, and on their distribution, considered as bearing on Geology. Report of the $13^{\text {th }}$ Meeting of the British Association for the advancement of Science, pp. 130-193. John Murray, London.

Fredj, G. - 1974. Stockage et exploitation des données en écologie marine. C: Considerations biogéographiques sur les peuplement benthique de la Méditerranée. Mém. Inst. Océanogr., Monaco, 7: 1-88

Fredj, G. and L. Laubier. - 1985. The deep Mediterranean benthos. In: M. Moraitou-Apostolopoulou and V. Kiortsis, (eds.), Mediterranean marine ecosystems, NATO Conference Series 1. Ecology, 8: 109-146.

Galil, B.S. and P.F. Clark. - 1993. A new genus and species of axiid (Decapoda, Thalassinidea) from the Levantine basin of the Mediterranean. Crustaceana, 64(1): 48-55.

Galil, B.S., A. Golik and M. Türkay. - 1995. Litter at the bottom of the sea: a sea bed survey in the Eastern Mediterranean. Mar. Poll. Bull., 30(1): 22-24.

Galil, B.S. and M. Goren. - 1994. The deep sea Levantine fauna new records and rare occurrences. Senckenberg. Marit., 25(1/3): 41-52

Galil, B.S. and H. Zibrowius. - 1998. First benthos samples from Eratosthenes seamount, Eastern Mediterranean. Senckenberg. Marit., 28(4/6): 111-121.

George, R.Y. and R.J. Menzies. - 1968. Additions to the Mediterranean deep-sea fauna. Revue roum. Biol. (zool.), 13: 367-383.

Gilat, E. and A. Gelman.- 1984. On the shark and fishes observed using underwater photography during a deep-water cruise in the eastern Mediterranean. Fish. Res., 2: 257-271.

Golani, D.- 1987. On deep-water sharks caught off the Mediterranean coast of Israel. Israel J. Zool., 34: 23-31.

Goren, M. and B.S. Galil.- 1997. New records of deep-sea fishes from the Levant Basin and a note on the deep-sea fishes of the Mediterranean. Israel J. Zool., 43: 197-203.

Goren, M. and B.S. Galil. - 2002. On the occurrence of Cataetyx laticeps Koefoed, 1927 and Ophidion barbatum Linnaeus, 1758 in the Levant Basin, Eastern Mediterranean, with a note on the deep sea fish community in this region. Cybium, 26(2): $150-152$.

Grecchi, G. - 1984. Molluschi planctonici e bentonici in sedimenti sapropelitici del quaternario della dorsale mediterranea. Boll. Malac., Milano, 20(1-4): 1-34.

Haedrich, R.L. and N.R. Merrett. - 1988. Summary atlas of deepliving demersal fishes in the North Atlantic Basin. J. Nat. Hist., 22: $1325-1362$ 
Hecht, A., N. Pinardi and A.R. Robinson. - 1988. Currents, water masses, eddies and jets in the Mediterranean Levantine Basin. J. Phys. Oceanogr., 18: 1320-1353.

Janssen, R. - 1989. Benthos-Mollusken aus dem Tiefwasser des östlichen Mittelmeeres, gesammelt während der "Meteor"Fahrt 5 (1987). Senckenberg. Marit., 20(5/6): 265-276.

Kallianiotis, A., K. Sophronidis, P. Vidoris and A. Tselepides. 2000. Demersal fish and megafaunal assemblages on the Cretan shelf and slope (NE Mediterranean): seasonal variationn in species density, biomass and diversity. Prog. Oceanogr., 46(2000): 429-455.

Klausewitz, W. - 1989. Deepsea and deep water fish of the Eastern Mediterranean, collected during the METEOR Expedition 1987. Senckenberg. Marit., 20(5/6): 251-263.

Krom, M.D., N. Kress, S. Brenner and L.I. Gordon. - 1991 Phosphorus limitation of primary productivity in the Eastern Mediterranean. Limnol. Oceanogr., 36: 424-432.

Marenzeller, E. - 1893. Berichte der Commission für Erforschung des östlichen Mittelmeeres, V. Zoologische Ergebnisse. I. Echinodermen, gesammelt 1890, 1891, und 1892. Denkschr. Akad. Wissen., Wien, 60: 1-24.

Moranta, J., C. Stefanescu, E. Massutí, N.B. Morles and D. Lloris. - 1998. Fish community structure and depth-related trends on the continental slope of the Balearic Islands (Algerian basin, western Mediterranean). Mar. Ecol. Prog. Ser., 171: 247-259.

Pérès J. M. - 1985. History of the Mediterranean biota and the colonization of the depths. In: R. Margalef (ed.), Key Enviroments Western Mediterranean, pp. 198-232. Pergamon Press, Oxford, New York.

Priede, I.G. and P.M. Bagley. - 2000. In Situ studies on deep-sea demersal fishes using autonomous unmanned lander platforms. In: R.N. Gibson and M. Barnes (eds.), Oceanogr. Mar. Biol. Ann. Rev., 38: 357-392.
Salas, C. - 1996. Marine bivalves from off the southern Iberian peninsula collected by The BALGIM and Fauna 1 Expeditions. Haliotis, 25: 33-100.

Sarà, M. - 1985. Ecological factors and their biogeographic consequences in the Mediterranean ecosystems. In: M. MoraitouApostolopoulou and V. Kiortsis (eds.), Mediterranean Marine Ecosystems. NATO Conference Series, New York, London. Plenum Press: 1-17.

Sorbe, J. C. and B. S. Galil. - 2002. The bathyal Amphipoda of the Levantine coast, Eastern Mediterranean. Crustaceana, 75(8): 957-968.

Stefanescu, C., D. Lloris and J. Rucabado. - 1992. Deep-living demersal fishes in the Catalan Sea (Western Mediterranean) below a depth of 1000 m. J. Nat. Hist., 26: 197-213.

Stefanescu, C., D. Lloris and J. Rucabado. - 1993. Deep-sea fish assemblages in the Catalan Sea (Western Mediterranean). Deep Sea Res., 40(4): 695-707.

Stephensen, K. - 1915. Isopoda, Tanaidacea, Cumacea, Amphipoda (excl. Hyperiidae). Report on the Danish Oceanographical expeditions 1908-1910 to the Mediterranean and adjacent seas, 2, (Biology) D.1: 1-53, Fgs. 1-33.

Udekem d'Acoz, C. - 1999. Inventaire et distribution des crustacés décapods de l'Atlantique nord-oriental, de la Méditerranée et des eaux continentals adjacentes au nord de $25^{\circ} \mathrm{N}$. Patrimoines naturels (M.N.H.N./S.P.N.), 40: 383 p.

Van Harten, D. - 1987. Ostracodes and the early Holocene anoxic event in the Eastern Mediterranean evidence and implications. Mar. Geol., 75: 263-269.

Yacobi, Y.Z., T. Zohary, N. Kress, A. Hecht, R.D. Robarts, M. Waiser, A.M. Wood and W.K.W. Li. - 1995. Chlorophyll distribution throughout the southeastern Mediterranean in relation to the physical structure of the water mass. J. Mar. Syst., 6: 179190.

APPENDIX 1. - List of species collected in the course of the IOLR deep Levantine campaigns 1988-1999 (*, New record for the eastern Mediterranean; **, New record for the Levantine Sea; ***, New record for the Israeli coast).

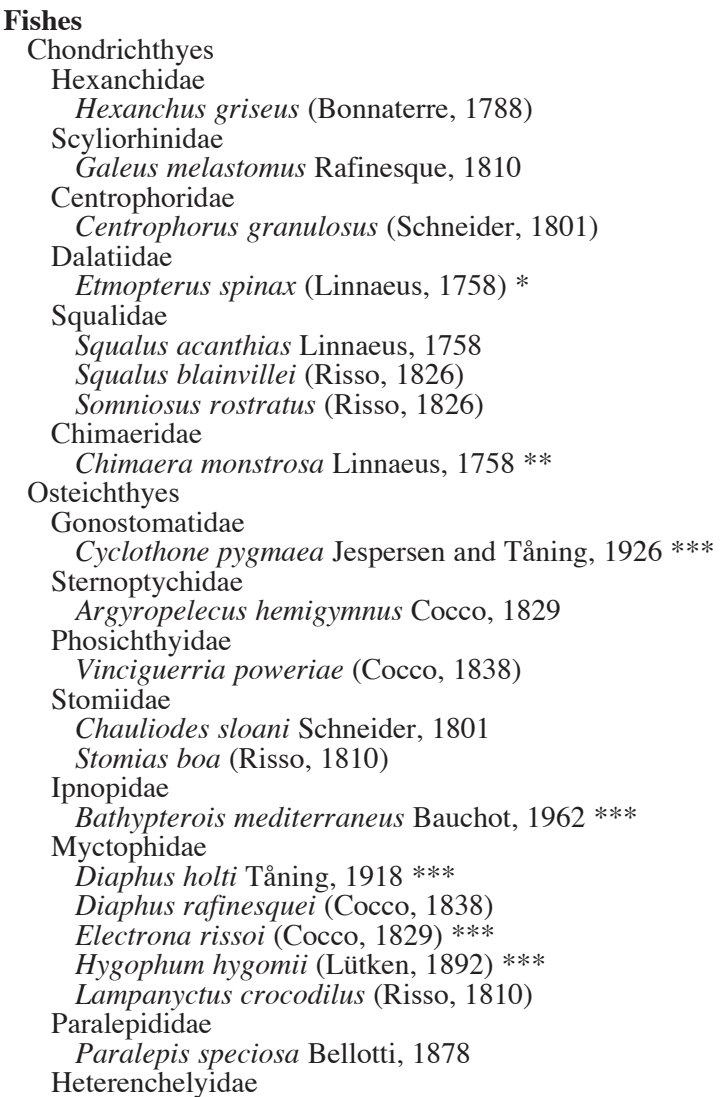

Panturichthys fowleri (Ben Tuvia, 1953)

Nettastomatidae

Nettastoma melanurum Rafinesque, 1810

Notacanthidae

Notacanthus bonapartei Risso, $1840 * *$

Polyacanthonotus rissoanus (Filippi and Vérany, 1859)*

Macrouridae

Caelorinchus caelorinchus (Risso, 1810)

Caelorinchus mediterraneus (Iwamoto and Ungaro, 2002) as

Coelorhynchus labiatus (Koehler, 1896)*

Coryphaenoides guentheri (Vaillant, 1888)**

Nezumia sclerorhynchus (Valenciennes, 1838) **

Phycidae

Phycis blennoides (Brünnich, 1768)

Trachichthyidae

Hoplostethus mediterraneus Cuvier, 1829

Bythitidae

Cataetyx laticeps Koefoed, 1927 *

Ophidiidae

Ophidion barbatum Linnaeus, 1758

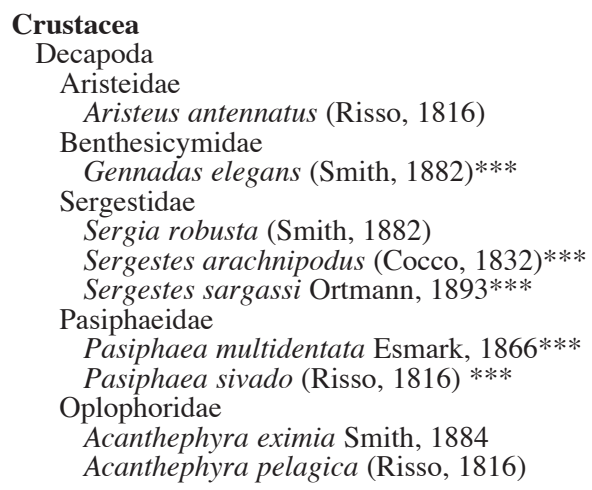


ApPENDIX 1 (Cont.). - List of species collected in the course of the IOLR deep Levantine campaigns 1988-1999 (*, New record for the eastern Mediterranean; **, New record for the Levantine Sea; ***, New record for the Israeli coast).

Nematocarcinidae

Nematocarcinus exilis Bate, 1888 ***

Pandalidae

Plesionika acanthonotus (Smith, 1882)**

Plesionika narval (Fabricius, 1787) ***

Crangonidae

Aegaeon lacazei (Gourret, 1887)**

Polychelidae

Polycheles typhlops Heller, 1862

Galatheidae

Munidopsis marionis (A. Milne Edwards, 1882) *

Axiidae

Levantocaris hornungae Galil and Clark, 1993

Portunidae

Bathynectes maravigna (Prestandrea, 1839) **

Geryonidae

Geryon longipes A. Milne Edwards, 1882**

Chaceon mediterraneus Manning and Holthuis, 1989**

Majidae

Dorynchus thomsoni Thomson, 1873***

Amphipoda

Eusiridae

Eusirus longipes Boeck, $1861 * *$

Rhachotropis caeca Ledoyer, $1977 * *$

Rhachotropis grimaldii (Chevreux, 1888) **

Rhachotropis rostrata Bonnier, 1896 **

Lepechinellidae

Lepechinella manco Barnard, 1973 **

Leucothoidae

Leucothoe lilljeborgi Boeck, 1861

Liljeborgiidae

Idunella pirata Krapp-Schickel, 1975 **

Lysianassidae

Orochomene grimaldii Chevreux, $1890 * * *$

Paracentromedon crenulatum (Chevreux, 1900) **

Tmetonyx similis (G. O. Sars, 1891) **

Tryphosella caecula (G. O. Sars, 1891) **

Tryphosites alleni Sexton, 1911 **

Oedicerotidae

Bathymedon monoculodiformis Ledoyer, 1983**

Oediceroides pilosus Ledoyer, $1983 * *$

Oediceroides brevicornis Lilljeborg, **

Pardaliscidae

Halice abyssi Boeck, 1871**

Phoxocephalidae

Harpinia dellavallei Chevreux, 1910 ***

Stegocephalidae

Stegophaloides christianiensis (Boeck, 1871) **

Synopiidae

Bruzelia typica Boeck, 1871 **

Ileraustroe ilergetes (Barnard, 1964) ***

Pseudotiron bouvieri Chevreux, 1895 ***

Syrrhoe affinis Chevreux, $1908 * *$

Cumacea

Bodotriidae

Bathycuma brevirostre (Norman, 1879)***

Cyclaspis longicaudata Sars, 1864***
Nannastacidae

Campylaspis glabra Sars, 1879***

Procampylaspis armata Bonnier, 1896***

Procampylaspis bonnieri Calman, 1906***

Procampylaspis mediterranea Ledoyer, 1988***

Styloptocuma gracillimum (Calamn, 1905)***

Diastylidae

Diastyloides serratus (Sars, 1865) ***

Leptostylis cf. gamoi Reyss, 1972***

Makrokylindrus longipes (Sars, 1871) ***

Leuconidae

Leucon ensis Bishop, 1981***

Lampropidae

Platysympus typicus (Sars, 1870) ***

Mollusca

Skeneidae Clark, 1851

Akritogyra conspicua (Monterosato, 1880) *

Rissoidae Gray, 1847

Alvania electa (Monterosato, 1874) *

Benthonella tenella (Jeffreys, 1869)

Conidae Rafinesque, 1815

Microdrillia loprestiana (Calcara, 1841)

Benthomangelia macra (Watson, 1881) **

Pyramidellidae Gray, 1840

Chrysallida flexuosa (Monterosato, 1874)

Turbonilla micans (Monterosato, 1875)*

Acteonidae D'Orbigny, 1842

Crenilabium exile (Jeffreys, 1870)

Cylichnidae Adams, H. and A., 1854

Roxania utriculus (Brocchi, 1814)

Yoldiidae Glibert and Van De Poel, 1965

Yoldia micrometrica (Seguenza, G., 1877)

Yoldiella philippiana (Nyst, 1845) **

Arcidae Lamarck, 1809

Bathyarca pectunculoides (Sacchi, 1834)

Bathyarca philippiana (Nyst, 1848)

Limidae Rafinesque, 1815

Limatula subauriculata (Montagu, 1808)

Pectinidae Rafinesque, 1815

Cyclopecten cf. hoskynsi (Forbes, 1844) **

Thyasiridae Dall, 1900

Thyasira granulosa (Monterosato, 1874) **

Thyasira oblonga (Monterosato, 1878) *

Thyasira eumyaria (Sars, M., 1870) **

Semelidae Stoliczka, 1870

Abra longicallus (Scacchi, 1834)

Kelliellidae Fischer, P., 1887

Kelliella abyssicola (Forbes, 1844)

Lyonsiidae Fischer, P., 1887

Allogramma formosa (Jeffreys, 1882) **

Cuspidariidae Dall, 1886

Cuspidaria rostrata (Spengler, 1793)

Cardiomyia costellata (Deshayes, 1835)

Scaphopoda Bronn, 1862

Entalina tetragona (Brocchi, 1814)

Echinodermata

Synallactidae

Mesothuria intestinalis (Ascanius and Rathke, 1805)*** 